\title{
Potensi Ekstrak Daun Malaysia (Chromolaena Odorata) Sebagai Pengawet Alami Ikan
}

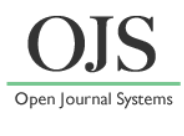

\author{
Nurhamidah*, Nova Riskiana, Cici Romayanti, Wangi Puspa Kartini dan Nadia Amida \\ Program Studi Pendidikan Kimia Jurusan PMIPA FKIP Universitas Bengkulu \\ *Email: nurhamidah@unib.ac.id
}

DOI: https://doi.org/10.33369/pendipa.5.1.30-35

\begin{abstract}
The aims of this study were to determine the potential of Malaysian leaf extract (chromolaena odorata) as a natural preservative for fish in an effort to avoid the use of formalin which is harmful to health. The extract used as a preservative comes from natural ingredients, namely Malaysian leaves which are extracted using pure water. Fish was soaked with Malaysian leaf extract using various concentrations of $10 \%, 20 \%, 30 \%$, and $40 \%$ for 1 hour, 2 hours, 3 hours, and 4 hours. The extract potential was seen from the results of the Total Volatile Base (TVB) test, which showed the freshness of the fish which could still be consumed after 12 hours, 18 hours 24 hours, 48 hours, and 72 hours intervals. Organoleptic test was carried out by looking at the color, aroma and texture of the fish immersed in the extract. The results showed that from the organoleptic test, it was found that the observation at 18 hours the fish began to experience deterioration in quality, while the chemical test results by measuring the TVB levels obtained that the Malaysian leaf extract can function as a fish preservative, with an optimum concentration of $40 \%$ and the optimum soaking time for 1 hour with an 18 hours observation time interval, where the TVB value is still below the allowable threshold for fish to be consumed, namely $29.1345 \% \mathrm{~N}$. The threshold for fish is still fit for consumption if the TVB value is below $30 \% \mathrm{~N}$.
\end{abstract}

Keywords: Cromolaena odorata; extract; total volatile base; natural fish preservative.

\begin{abstract}
ABSTRAK
Penelitian ini bertujuan untuk mengetahui potensi ekstrak daun malaysia (chromolaena odorata) sebagai pengawet alami ikan dalam upaya menghindari penggunaan formalin yang berbahaya terhadap kesehatan. Ekstrak yang digunakan sebagai pengawet bersumber dari bahan alami, yaitu daun Malaysia yang diekstrak menggunakan air murni. Ikan di rendam dengan ekstrak daun malaysia menggunakan variasi konsentrasi 10\%, 20\%, 30\%, dan 40\% selama 1 jam, 2 jam, 3 jam, dan 4 jam. Potensi ektstrak dilihat dari hasil uji Total Volatil Base (TVB) yang menunjukkan tingkat kesegaran ikan yang masih dapat dikonsumsi setelah selang waktu 12 jam, 18 jam 24 jam, 48 jam, dan 72 jam. Uji organoleptik dilakukan dengan melihat warna, aroma dan tekstur dari ikan yang telah direndam dalam ekstrak. Hasil penelitian menunjukkan bahwa dari uji organoleptik diperoleh bahwa pengamatan pada waktu 18 jam ikan mulai mengalami kemunduran mutu, sedangkan hasil uji kimia dengan mengukur kadar TVB diperoleh ekstrak daun malaysia dapat berfungsi sebagai pengawet ikan, dengan kondisi optimum konsentrasi $40 \%$ dan lama waktu perendaman optimum selama 1 jam dengan selang waktu pengamatan 18 jam, dimana nilai TVB masih dibawah ambang batas yang diperbolehkan untuk ikan dikonsumsi yaitu 29,1345\% N. Ambang batas ikan yang masih layak dikonsumsi jika nilai TVB berada dibawah $30 \% \mathrm{~N}$.
\end{abstract}

Kata kunci: Cromolaena odorata; ekstraks tumbuhan; basa mudah menguap; pengawet alami ikan. 


\section{PENDAHULUAN}

Ikan merupakan bahan pangan fungsional yang mempunyai arti penting bagi kesehatan, dan sangat kaya dengan protein yang dibutuhkan untuk pertumbuhan terutama untuk anak-anak (Wally, dkk. 2015). Menurut laporan Shah, et al. (2018) hasil perikanan merupakan sumber daya utama dalam menyumbangkan makanan. Produksi ikan melalui budidaya terus memegang peranan penting, dimana pada tahun 2012, total produksi ikan dunia adalah 185 juta ton. Ikan dapat membantu menyembuhkan berbagai penyakit, karena ikan dapat mensuplai kalsium, vitamin A, zat besi dan zink.

Indonesia merupakan Negara maritim yang juga produksi ikannya sangat melimpah, salah satunya Provinsi Bengkulu. Ikan sangat mudah mengalami pembusukan, sehingga diperlukan perlakuan selanjutnya seperti dilakukan pengawetan (Tahar, dkk. 2017). Selama ini pengawetan dilakukan dengan memberi garam dan dikeringkan, tetapi ada juga yang menggunakan pengawet sintetis yang sangat berbahaya bagi kesehatan seperti bahan kimia formalin. Indonesia merupakan negara tropis yang memiliki kekayaan flora yang sangat melimpah, dan sudah dimanfaatkan oleh nenek moyang kita sebagai obat untuk pencegahan dan pengobatan berbagai macam penyakit. Tumbuhan mengandung senyawa metabolit sekunder yang mempunyai beberapa aktifitas diantaranya antioksidan dan antibakteri (Andriani and Mohamad, 2013), sehingga dimungkinkan dapat dimanfaatkan sebagai pengawet ikan.

Beberapa peneliti telah melaporkan potensi ekstrak tanaman sebagai pengawet, seperti seperti laporan Dewi, dkk.(2019) ekstrak buah murbei konsentrasi 30\% dengan lama perendaman 1 jam paling optimal terbukti mampu menurunkan nilai $\mathrm{pH}$ dan kadar TVB tetapi tidak mempengaruhi kadar air. Menurut laporan Pribadi, dkk. (2018) ekstrak air dari buah $F$. inermis Roxb L memiliki potensi untuk digunakan sebagai bahan pengawet ikan karena dapat menurunkan nilai $\mathrm{pH}$ dan kadar TVB. Menurut Daud, (2017) kadar TVB digunakan untuk mengukur tingkat kesegaran ikan dan sebagai batasan yang layak untuk dikonsumsi, dimana ikan dinyatakan telah busuk ketika memiliki kadar TVB >30 mgN/100 g. Hasil penelitian Mulyanto, dkk. (2017) ekstrak daun jambu biji merah juga dapat menurunkan nilai TVB ikan dan mengandung senyawa metabolit sekunder tanin, alkaloid dan flavonoid. Hasil penelitian Arizka, (2017) kualitas dan daya simpan ikan kakap merah dapat bertahan lebih lama setelah direndam menggunakan ektrak daun kelor pada perlakuan berat daun kelor $75 \mathrm{~g}$, Aquades $100 \mathrm{~mL}$ dengan lama perendaman 30 menit dengan koloni bakteri $2.05 \times 10^{6} \mathrm{cfu} / \mathrm{g}$, kadar air $43.3 \%$ dengan $\mathrm{pH} 6$.

Salah satu spesies tanaman yang diduga dapat digunakan sebagai pengawet ikan adalah spesies tanaman Cromolaena odorata yang biasa di sebut tanaman malaysia oleh masyarakat bengkulu dan sekitarnya. Tanaman malaysia ini berbulu dan daunnya mengeluarkan bau aromatik yang menyengat saat dihancurkan. Daunnya mengandung beberapa senyawa utama seperti tannin, fenol, flavonoid, saponin dan steroid. Minyak essensial dari daunnya memiliki kandungan $\alpha$-pinene, cadinene, camphora, limonene, $\beta$-caryophyllene dan candinol isomer (Inya-Agha, et al. 1987).

Berdasarkan kandungan senyawa metabolit sekunder yang terdapat pada daun tanaman malaysia ini, yang mengandung senyawa fenol dan flavonoid dan menurut Butkhup, et al. (2013) senyawa ini mempunyai aktivitas sebagai antioksidan dan antibakteri, diperkirakan daun tanaman ini dapat digunakan sebagai bahan pengawet alami ikan. Terutama untuk ikan yang banyak terdapat di daerah Bengkulu, seperti ikan beledang.

\section{METODE PENELITIAN}

Penelitian dilakukan di laboratorium Program Studi Pendidikan Kimia Fakultas Keguruan dan Ilmu Pendidikan dan laboratorium kimia jurusan Kimia Fakultas Matematika dan Ilmu Pengetahuan Alam Universitas Bengkulu.

\footnotetext{
Alat

Alat-alat yang digunakan dalam penelitian ini diantaranya:

labu Erlenmeyer, batang pengaduk, pipet tetes, kaca arloji, Blender Laboratorium, neraca analitik, gelas ukur, gelas beker, labu ukur, pisau/curter, botol vial, cawan conway, buret, corong, sudip, dan aluminium Foil.
} 


\section{Bahan}

Bahan yang digunakan adalah ikan beledang (Trichiurus lepturus) yang diambil di pantai jakat Bengkulu, daun malaysia (Chromolaena Odorata), Etanol, aquades steril, kertas saring, asam Trikloroasetat (TCA), Potassium Karbonat, Vaselin steril, asam Borat, asam Klorida teknis, Metil Red.

\section{Prosedur Penelitian \\ Pembuatan Ekstrak Daun Malaysia}

Daun tanaman malaysia yang diambil dari lingkungan kampus Universitas Bengkulu, dibersihkan dan dipotong menjadi kecil-kecil. Selanjutnya daun yang sudah berukuran kecil di blender dan direndam dalam aquades lalu disaring menggunakan kertas saring. Filtrat yang diperoleh merupakan ekstrak daun malaysia yang selanjutnya digunakan untuk sampel uji sebagai pengawet ikan.

\section{Perendaman Ikan}

Semua peralatan disterilisasi dengan menggunakan alkohol $96 \%$ kemudian dikeringkan dan selanjutnya disiapkan ikan Beledang segar yang sudah dibersihkan. Masing-masing ikan beledang segar diberikan perlakuan yang berbeda dengan direndam kedalam larutan ekstrak daun malaysia. Larutan uji dibuat dengan mengencerkan ekstrak menggunakan aquades dengan variasi konsentrasi 10\%, 20\%, 30\%, dan 40\%. Sebagai kontrol digunakan ikan yang tanpa perendaman. Masing-masing ikan direndam kedalam larutan ekstrak daun malaysia dengan variasi konsentrasi 10\%, 20\%, 30\%, dan 40\% dengan variasi lama perendaman 1 jam, 2 jam, 3 jam, dan 4 jam. Selanjutnya dilakukan pengamatan mutu kemunduran ikan selama selang waktu 12 jam, 18 jam, 24 jam, 48 jam, dan 72 jam dengan uji organoleptik dan nilai TVB.

\section{Uji Organoleptik}

Uji organoleptik dilakukan pada parameter yaitu warna insang, aroma, dan tekstur daging karena suka atau tidaknya konsumen terhadap suatu produk dipengaruhi oleh warna, aroma, dan tekstur (Laksmi, 2012).

Penentuan ikan segar dengan uji organoleptik sederhana:

\section{Insang}

Insang pada ikan segar memiliki warna yang cenderung merah segar ataupun merah muda tidak kusam serta terdapat lendir jernih yang menutupi insang.

2. Mata

Kondisi mata pada ikan segar cenderung datar atau bahkan cembung, kalau mata ikan sudah cenderung cekung artinya ikan sudah mengalami kemunduran mutu meski bukan berarti sudah busuk. Warna mata pada ikan segar juga terang dan jernih.

3. Daging

Menentukan kesegaran ikan dengan melihat daging ikan sebenarnya bisa diketahui dengan cara menyayatnya atau memilet ikan tersebut. Ciri ikan segar warna daging terang, teksturnya kenyal dan kokoh atau dapat dengan menekan daging ikan dengan jari, jika hasilnya cepat kembali ke kondisi semula serta daging itu terasa tidak terlalu keras dan lembek maka ikan tersebut masih segar.

\section{Uji Total Volatil Base (TVB)}

Prosedur awal yaitu dengan membuat filtrat yang berasal dari $25 \mathrm{~g}$ daging ikan dan $75 \mathrm{~mL}$ TCA $7.5 \%$ yang dihaluskan dengan blender dan disaring. Kemudian disiapkan 2 buah cawan Conway untuk masing-masing pengujian. Cawan Conway 1, diisi $1 \mathrm{~mL}$ larutan asam borat pada cawan bagian dalam, sedang pada sisi kanan luar diisi filtrat dan sisi sebelah kiri diisi $\mathrm{K}_{2} \mathrm{CO}_{3}$ masing-masing sebanyak $1 \mathrm{~mL}$. Cawan Conway 2 digunakan untuk blanko dengan filtrat sampel diganti dengan larutan TCA 7.5\%. Cawan ditutup dan digerakkan memutar agar larutan pada bagian luar tercampur. Cawan conway diinkubasi pada suhu $37{ }^{\circ} \mathrm{C}$ selama 2 jam, selanjutnya asam borat dititrasi dengan $\mathrm{HCl}$ $0.002 \mathrm{~N}$, dimana titik akhir ditandai dengan timbulnya warna merah muda.

\section{HASIL DAN PEMBAHASAN Uji Potensi Ekstrak Daun Malaysia Sebagai Pengawet Alami}

Perendaman larutan ekstrak daun Malaysia terhadap ikan, menunjukkan bahwa adanya daya hambat terhadap pertumbuhan baktari yang ada pada ikan. Berdasarkan penelitian yang 
dilakukan nilai TVB lebih rendah di bandingkan dengan tanpa perlakuan. Dari hasil pengukuran kadar TVB dan uji organoleptik didapatkan bahwa perendaman ikan dalam ekstrak daun Malaysia berpotensi sebagai penghambat kemunduran mutu ikan pada konsentrasi tertentu.

\section{Penentuan Konsentrasi dan Lama Perendaman Optimum Ekstrak}

Penentuan konsentrasi dan lama perendaman optimum mengacu pada 4 variasi konsentrasi yaitu $10 \%, 20 \%, 30 \%$ dan $40 \%$ serta lama perendaman 1 jam, 2 jam, 3 jam dan 4 jam. Selanjutnya ikan beledang yang telah direndam dengan variasi konsentrasi dan waktu, di simpan di tempat terbuka pada suhu ruang dan diamati setiap 12 jam,18 jam,24 jam, 48 jam, dan 72 jam. Selanjutnya dilakukan uji Organoleptik dan uji kadar TVB.

\section{Hasil Analisis Organoleptik}

Uji organoleptik terhadap bau, insang, mata, tekstur daging dari ikan beledang terlihat perubahan kemunduran mutu seiring dengan kemunduran waktu. Perubahan mutu ikan terjadi pada pengamatan 18 jam dengan lama perendaman selama 2 jam. Dalam kondisi ini ikan beledang masuk dalam fase rigor mortis (kaku), selanjutnya dari jam ke 18 sampai jam 24 ikan beledang terus mengalami kemunduran mutu karena daging ikan mudah terlepas dari kulit dan isi perut berbau tengik.

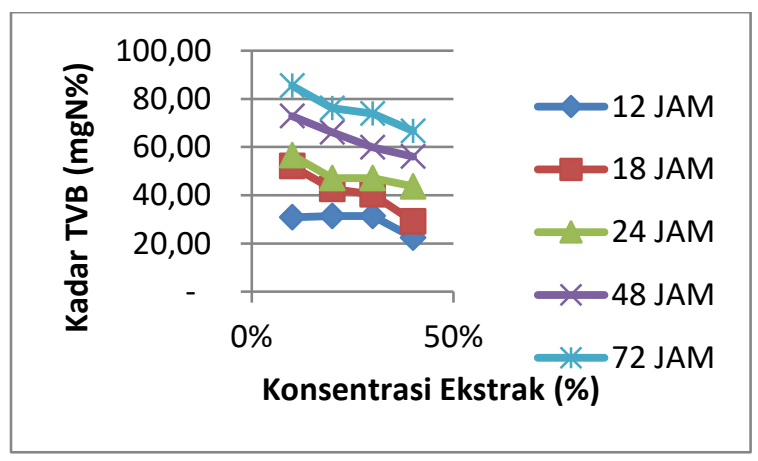

Gambar 1: Grafik Hasil analisis kadar TVB 1 jam perendaman

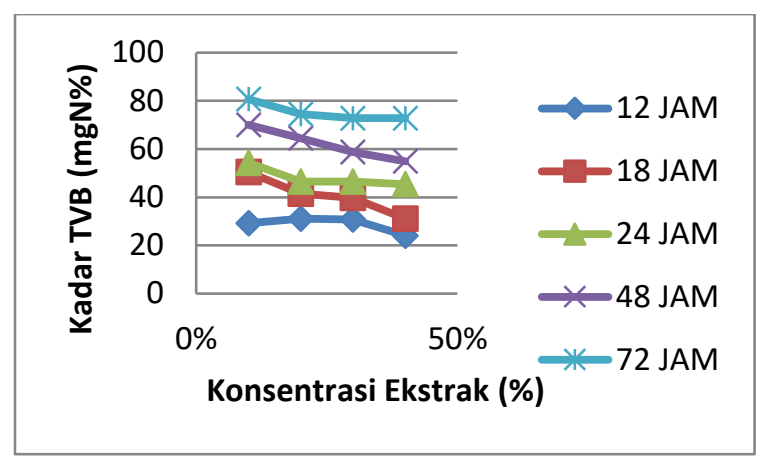

Gambar 2: Grafik Hasil analisis kadar TVB 2 jam perendaman

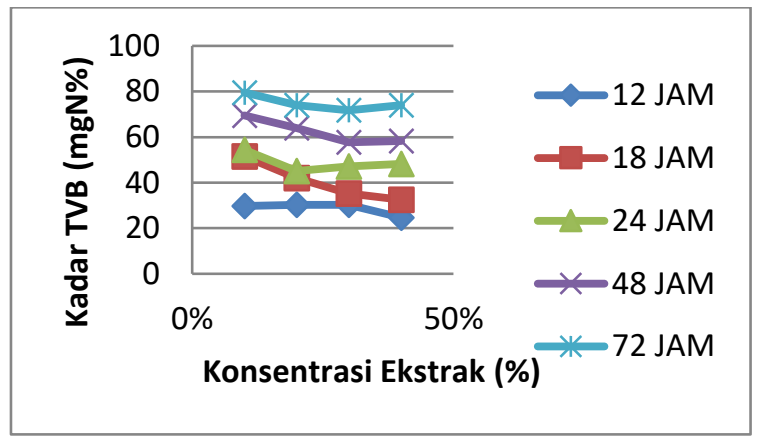

Gambar 3: Grafik Hasil analisis kadar TVB 3 jam perendaman

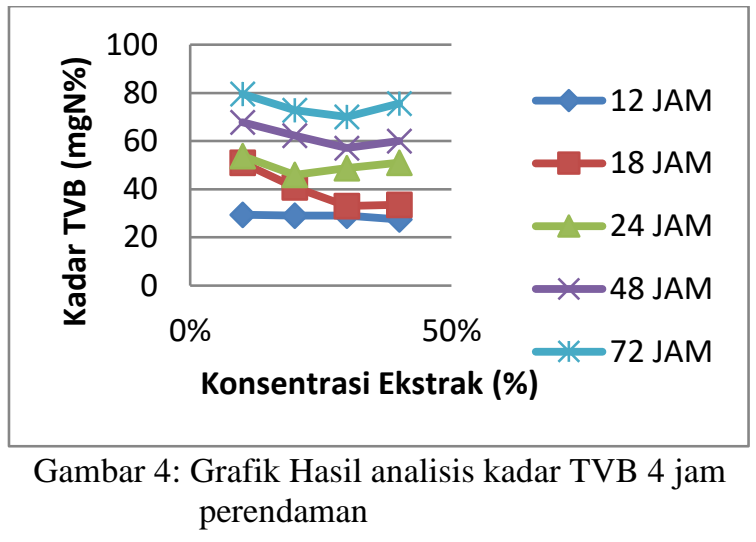

Hasil Analisis nilai Total Volatil Base (TVB)

Kadar TVB digunakan sebagai batas penolakan produk pada standard dan spesifikasi komersial. Sejalan dengan proses pembusukan ikan, ada beberapa senyawa yang terbentuk selama kemunduran ikan. Kadar TVB tergantung pada mutu kesegaran ikan, makin menurun mutu ikan maka kadar TVB semakin meningkat. Analisis kadar TVB ikan beledang pada variasi lama perendaman 1 jam, 2 jam, 3 jam dan 4 jam dapat di lihat pada gambar 1, 2, 3 dan 4. 
Berdasarkan pengukuran kadar TVB pada pengamatan 12 jam, 24 jam, 32 jam, 48 jam dan 72 jam setelah perendaman dengan berbagai variasi konsentrasi didapatkan bahwa, semakin lama penyimpanan ikan beledang segar pada suhu ruang maka kadar TVB semakin besar. Dari gambar 1, 2, 3 dan 4 terlihat kadar TVB ikan yang direndam dengan ekstrak daun Malaysia mengalami penurunan di sebabkan adanya kombinasi perlakuan yang menyebabkan jumlah bakteri yang terdapat pada ikan dapat di tekan, sehingga aktivitas bakteri proteolitik tidak maksimal dalam menguraikan protein. Selain itu senyawa metabolit sekunder yang ada pada daun Malaysia juga mempunyai aktifitas sebagai antioksidan yaitu senyawa yang dapat menghambat reaksi oksidasi dengan mengikat radikal bebas dan molekul yang sangat reaktif, akibatnya mengurangi terbentuknya senyawasenyawa basa akibat oksidasi lemak, sehingga berperan untuk mempertahankan mutu produk pangan.

Kadar TVB ikan beledang setelah 12 jam perlakuan menunjukkan mutu ikan sudah mulai menurun tetapi masih layak di konsumsi karena belum melampaui batas kadar TVB untuk ikan yang boleh dikonsumsi. Sedangkan pada pengamatan 18 jam setelah perlakuan didapatkan kadar TVB semakin meningkat, tetapi untuk konsentrasi ekstrak daun malyasia yang digunakan $40 \%$ dengan lama perendaman 1 jam masih memiliki nilai TVB di bawah batas ikan yang boleh dikonsumsi yaitu 29,1345 mg N\%. Sedangkan perlakuan lainnya sudah berada diatas ambang batas kesegaran ikan yaitu di atas angka $30 \mathrm{mg}$ N\% ikan yang layak dikonsumsi.

\section{KESIMPULAN}

Berdasarkan hasil penelitian yang telah dilakukan dapat disimpulkan sebagai berikut:

1. Hasil penelitian menunjukkan bahwa daun malaysia berpotensi sebagai pengawet ikan, berdasarkan dari hasil uji organoleptik pada parameter warna insang dan mata, tekstur dan bau. Berdasarkan uji organoleptik yang di lakukan ikan sudah tidak layak untuk di konsumsi pada pengamatan 24 jam setelah perlakuan pada semua variasi konsentrasi dan lama perendaman.

2. Berdasarkan uji TVB, kondisi optimum ekstrak daun malaysia yang dapat digunakan sebagai pengawet ikan beledang adalah pada konsentrasi ekstrak 40\%, waktu perendaman 1 jam dan lama pengamatan setelah perlakuan 18 jam.

\section{DAFTAR PUSTAKA}

Andriani, Y., Mohamad, H. 2013. Potential Therapeutic Lead Coumpounds from Our Local Coastal Forest. The $26^{\text {th }}$ Symposium of Malaysia Analytical Sciences (SKAM 26). Khuching Serawak Malaysia 4-5 Desember.

Arizka, D.A. 2017. Kualitas dan Daya Simpan Ikan Kakap Merah dengan Daun Kelor sebagai Pengawet Alami. FKIP Universitas Muhammadiyah Surakarta. eprints. ums.ac.id

Butkhup, L., Wannee, S., Supachai, S. 2013. Phenolic composition and antioxidant activity of white mulberry (Morus alba L.) Fruits. International Journal of Food Science \& Technology,: 48 (5): 934-940.

Daud, A., Sahriawati., Suriati. 2017. Pengembangan Prosedur Analisis Total Volatil Bases dengan Menggunakan Indikator Alami. https://ppnp.ejournal.id/agro_ppnp/article/view/148/95.

Dewi, D.N., Nurhamidah., Chandra, I.N. 2019. Pemanfaatan Ekstrak Buah Morus alba L. (Murbei) sebagai Pengawet Alami Ikan Selaroides leptolepis (Selar). Alotrop. Jurnal Pendidikan dan Ilmu Kimia. 3(1): 17. p-ISSN 2252-8075 e-ISSN 2615-2819.

Inya-Agha, S. I., Oguntimein, B. O., Sofowora, A., \& Benjamin, T. V. 1987. Phytochemical and antibacterial studies on the essential oil of Eupatorium odoratum. International Journal of Crude Drug Research, 25(1), 4952.

Laksmi, R. T., A. M. Legowo dan Kusrahayu. 2012. Daya ikat air, $\mathrm{pH}$ dan sifat organoleptik chicken nugget yang disubstitusi dengan telur rebus. Animal Agriculture Journal. (1):453 - 460.

Mulyanto, S., Sumardianto., Amalia, U. 2017. Pengaruh Penambahan Ekstrak Daun Jambu Biji Merah (Psidium guajava) terhadap Daya Simpan Ikan Nila Merah (Oreochromis niloticus) pada Suhu Dingn. J. Peng. Dan Biotek. Hasil Pi. 6(4): 1-7. 
Pribadi, A., Nurhamidah., Elvinawati. 2018. Pemanfaatan Ekstrak Air Buah Flacourtia inermis Roxb. (Lobi-lobi) sebagai Pengawet Ikan Laut. Alotrop. Jurnal Pendidikan dan Ilmu Kimia. 2(1): 1-7. ISSN 2252-8075

Shah, S.B.H., Mu, Y., Abbas, G., Pavase, T.R., Mohsin, M., Ali, M., Noman, M. and Soomro, M.A. 2018. An economic analysis of the fisheries sector of Pakistan (19502017): Challenges, opportunities and development strategies. International Journal of Fisheries and Aquatic Studies 2018; 6(2): 515-524
Tahar, N., Fitrah, M., David, N.A.M. 2017. Penentuan Kadar Protein Daging Ikan Terbang (Hyrundicthys oxycephalus) Sebagai Substitusi Tepung Dalam Formulasi Biskuit, JF FIK UINAM, :5(4):251-257.

Wally, E., Mentang, F., Montolalu, R.I. 2015. Kajian Mutu Kimiawi Ikan Cakalang (Katsuwonus pelamis L.) Asap (Fufu) Selama Penyimpanan Suhu Ruang dan Suhu Dingin. Jurnal Media Teknologi Hasil Pertanian. 3(1): 7-12. 